\title{
PENINGKATAN HASIL BELAJAR FISIKA MELALUI MODEL PROBLEM BASED LEARNING (PBL)
}

\author{
Received: 26-12-2020
}

Revised: 12-01-2021

Accepted: 08-02-2021

\section{Suripta}

Ssekolah Menengah Atas Negeri 106 Jakarta

Email: Suripta106@gmail.com

\begin{tabular}{l}
\hline Kata kunci: \\
student \\
achievements, \\
model of problem \\
based learning \\
\hline
\end{tabular}

\begin{abstract}
This research is aiming to improve student's achievements in learning physics. This research uses classroom action research with data analysis using qualitative descriptive. This research was conducted at SMAN 106 Jakarta with two cycles. Test results and documentation used to collect data SMAN 106 is chosen as a place of research with two-cycle. From the research we get an average score 72 on the pre-cycle assessment, there an increasing score on the first and second phases became 80,00 and 92,00. From the 1st and 2 st fase, it shows that the result of the model the learning has been improved after conduct a model learning with problem-based learning. So, we can conclude that problem-based learning can improve student achievements in physics.
\end{abstract}

\section{Keywords:}

hasil belajar, dan pembelajaran model problem based learning,

\begin{tabular}{l} 
Abstrak \\
\hline Penelitian ini bertujuan untuk meningkatkan hasil belajar \\
siswa dalam pembelajaran fisika. Penelitian ini menggunakan \\
jenis penelitian tindakan kelas dengan analisis data \\
menggunakan pendekatan deskriptif, kualitatif Penelitian ini \\
dilakukan di SMAN 106 Jakarta dengan menggunakan dua \\
siklus. Hasil penelitian diperoleh rata-rata hasil belajar 72.00 \\
pada penilaian pra-siklus, menjadi 80.00 pada siklus pertama \\
dan 92,00 pada siklus yang ke-dua. Dari hasil siklus pertama \\
dan kedua menunjukan bahwa hasil pembelajran sudah \\
mengalami peningkatan setelah pemblajaran menggunakan \\
model pembelajaran problem based learning. Dari analisi \\
hasil penelitian tindakan kelas ini maka dapat disimpulkan \\
bahwa Pembelajaran Model problem based Learning dapat \\
meningkatkan hasil belajar siswa dalam pembelajaran fisika
\end{tabular}




\section{PENDAHULUAN}

Dalam suatu proses pembelajaran agar tujuan pembelajaran yang telah direncanakan dapat tercapai, terdapat beberapa aspek yang perlu diperhatikan antara lain: pendekatan pembelajaran, strategi pembelajaran, model pembelajaran, teknik pembelajaran dan metode pembelajaran. Aspek-aspek di atas sangat penting karena dapat mempengaruhi keberhasilan dalam proses pembelajaran, dimana dalam proses belajar mengajar dipenuhi dengan berbagai interaksi antara guru dan siswa untuk mencapai tujuan pembelajaran tertentu yang telah direncanakan ${ }^{1}$.

Peserta didik merupakan individu yang pada dasarnya memiliki banyak perbedaan satu dengan yang lainnya. Perbedanan itu antara lain daya pikir, latar belakang sosial dan psikologis. Perbedaan ini bagi seorang pendidik merupakan masalah yang membuat tidak maksimalnya hasil pembelajaran yang didapat oleh peserta didik dalam proses pembelajaran. Seorang pendidik atau guru dituntut untuk melakukan inovasi-inovasi pada hal mendasar yang ada pada proses pembelajaran².

Pelajaran fisika merupakan pelajaran yang membutuhkan inovasi dalam proses pembelajarannya, hal ini dapat diindikasikan disetiap pembelajaran banyak peserta didik merasa kesulitan dalam menghadapi soal-soal fisika yang pada akhirnya dapat menyebabkan nilai fisika peserta didik rendah ${ }^{3}$. Rendahnya nilai fisika peserta didik ini juga disebabkan oleh kurangnya penguasaan guru dalam mengelola kelas. Pengelolaan kelas yang baik akan menimbulkan interaksi yang baik pula antara guru dan siswa. Oleh karena itu proses pembelajaran harus dirancang sebaik mungkin agar tujuan pembelajaran dapat tercapai.

${ }_{1}^{1}$ Donni Juni Priansa, Pengembangan Strategi Dan Model Pembelajaran, 1st ed. (Bandung: CV.Pustaka Setia, 2017); A. Rusdiana, Konsep Inovasi Pembelajaran (Bandung: Pustaka Setia, 2014); Zainal Arifin, "Lingkungan Pendidikan Berperan Aktif Menumbuhkan Motivasi Belajar Siswa Menurut Syaikh AlZarnuji, Dalam Kitab Ta'limul Muta'allim," Al Qodiri: Jurnal Pendidikan, Sosial Dan Keagamaan 7, no. 2 (2014): 32-40; Rivika Alda, Helen Boholano, and Filomena Dayagbil, "Teacher Education Institutions in the Philippines towards Education 4.0," International Journal of Learning, Teaching and Educational Research 19, no. 8 (September 26, 2020), http://www.ijlter.org/index.php/ijlter/article/view/2449.

2 Deni Darmawan, Inovasi Pendidikan, Pendekatan Praktik Teknologi Multimedia Dan Pembelajaran Online, ketiga, 3 (Bandung: PT Remaja Rosdakarya, 2014); Sekar Dwi Ardianti et al., "Respon Siswa Dan Guru Terhadap Modul Ethno-Edutainment Di Sekolah Islam Terpadu," Edukasia: Jurnal Penelitian Pendidikan Islam 14, no. 1 (June 24, 2019): 1-24, https://doi.org/10.21043/edukasia.v13i2.3693; Hamid Darmadi, “Tugas, Peran, Kompetensi, Dan Tanggung Jawab Menjadi Guru Profesional," Edukasi: Jurnal Pendidikan 13, no. 2 (April 23, 2016): 161-74, https://doi.org/10.31571/edukasi.v13i2.113.

3 Muhammad Satriawan and Rosmiati Rosmiati, "Pengembangan Bahan Ajar Fisika Berbasis Kontekstual Dengan Mengintegrasikan Kearifan Lokal Untuk Meningkatkan Pemahaman Konsep Fisika Pada Mahasiswa," JPPS (Jurnal Penelitian Pendidikan Sains) 6, no. 1 (2017): 1212-17. 
Dari proses pembelajaran yang telah dilakukan penulis pada kompetensi dasar menganalisis besaran-besaran fisis gelombang berjalan dan gelombang stasioner pada berbagai kasus nyata, didapati hasil : rata-rata nilai ulangan kelas adalah 72,00. Siswa yang belum tuntas dalam pembelajaran berjumlah 24 siswa (66,66 \% dari 36 siswa), sedangkan yang tuntas adalah 12 siswa ( 33,33\% dari 36 siswa). Hal ini mengindikasikan bahwa dalam proses pembelajaran ada beberapa kendala yang menyebabkan lebih dari 50 \% siswa belum mencapai ketuntasan. Kendala-kendala yang teramati antara lain siswa kurang aktif, terlihat bosan dan suasana pembelajaran kurang bergairah,

Untuk itu perlu dicari solusi agar pembelajaran fisika dapat menumbuhkan kemampuan berpikir kreatif, sehingga dapat meningkatkan hasil belajar dan aktivitas siswa dalam pembelajaran, pembelajaran yang bermakna, pembelajaran yang menimbulkan motivasi dan menumbuhkan berpikir kritis.

Untuk itu perlu dicari solusi agar pembelajaran fisika dapat menumbuhkan kemampuan berpikir kreatif dan dapat meningkatkan aktivitas siswa, yang diharapkan dapat meningkatkan hasil belajar siswa. Salah satu solusi yang dapat penulis tawarkan adalah pembelajaran dengan model Problem Base Learning4. Oleh karena itu perlu diadakan penelitian tindakan kelas untuk membuktikan bahwa melalui penerapan model problem based learning dapat meningkatkan hasil belajar siswa dalam pembelajaran fisika.

Dipilihnya model pembelajaran problem based learning sebagai alternatif model pembelajaran yang akan digunakan di kelas XI MIPA SMAN 106 Jakarta karena beberapa kelebihan dari model tersebut. Adapun kelebihan model problem based learning antara lain: 1). Model pembelajaran problem based learning dapat memberikan pembelajaran bermakna. 2). Siswa mengintegrasikan pengetahuan dan ketrampilan dalam kontek yang relevan. 3). Dapat meningkatkan kemampuan berpikir kritis, menumbuhkan inisiatif dalam belajar, motivasi internal untuk belajar, dan dapat mengembangkan hubungan interpersonal dalam belajar ${ }^{5}$.

\footnotetext{
4 Marhamah Saleh, "Strategi Pembelajaran Fiqh Dengan Problem-Based Learning," Jurnal Ilmiah Didaktika: Media Ilmiah Pendidikan Dan Pengajaran 14, no. 1 (August 1, 2013), https://doi.org/10.22373/jid.v14i1.497.

5. Pd Ngalimun and M. Pd, “Strategi Dan Model Pembelajaran,” Yogyakarta: Aswaja Pessindo, 2014.
} 
Penelitian ini juga didasarkan pada beberapa penelitian yang berkaitan dengan pembelajaran model problem based learning sebelumnya. Adapun peneliti yang telah melakukan penelitian yang berkaitan dengan model pembelajaran based learning antara lain penelitian Asri Fitriani dengan judul "upaya peningkatan hasil belajar siswa dengan model problem based learning (PBL) pada subtema hidup rukun dirumah (Penelitian Tindakan Kelas di kelas II SDN 025 Cikutra Kota Bandung)" diperoleh hasil bahwa terjadi peningkatan hasil belajar siswa saat pembelajaran dengan menggunakan model Problem Based Learning (PBL) ${ }^{6}$.

Sedangkan penelitian yang telah dilakukan Melly Safitri, Yennita dan Irdam Idrus dengan judul "upaya meningkatkan aktivitas dan hasil belajar IPA siswa melalui penerapan model problem based learning (PBL) kelas VII 2 SMP Negeri 14 kota Bengkulu tahun ajaran 2016/2017, pada materi dampak pencemaran bagi kehidupan," memperoleh data bahwa aktivitas siswa pada siklus I diperoleh skor rata-rata 30,3 (Baik), dan pada siklus II skor aktivitas siswa menjadi 30,6 (Baik). Sedang ketuntasan belajar klasikal diperoleh persentase sebesar 82,3\% yang termasuk kedalam kriteria belum tuntas dan pada siklus II hasil belajar siswa mengalami peningkatan dengan ketuntasan belajar klasikal yaitu 85,2\% dan termasuk dalam kriteria tuntas. Dengan dmikian maka dari analisi hasil penelitian tersebut juga dapat disimpulkan bahwa model Pembelajaran Problem Based Learning (PBL) dapat meningkatkan aktivitas guru dan aktivitas siswa serta hasil belajar siswa kelas VII2 SMPN 14 Kota Bengkulu7.

Penelitian juga telah dilakukan oleh Retno Puji Astuti dan Iwan Junaedi dengan judul " peningkatan aktivitas dan hasil belajar melalui pbl pada siswa kelas X SMA Negeri 4 Pekalongan kelas X6", pada bulan Februari sampai Juli 2013 memberikan hasil penelitian pada siklus I, siswa yang tuntas adalah 19 dari 30 siswa atau 63,3\% dan siswa yang tidak tuntas adalah 11 dari 30 siswa atau 26,7 \%. Sedangkan hasil pada siklus II, siswa yang tuntas 25 dari 30 siswa atau 83,3\%. Terdapat peningkatan $20 \%$ dari siklus I Sedangkan keaktifan siswa pada siklus I adalah 20 siswa dari 30 siswa

${ }^{6}$ ASRI FITRIANI ALIFAH, “Upaya Peningkatan Hasil Belajar Siswa Dengan Model Problem Based Learning (Pbl) Pada Subtema Hidup Rukun Dirumah (Penelitian Tindakan Kelas Di Kelas Ii Sdn 025 Cikutra Kota Bandung)" (other, FKIP UNPAS, 2018), http:/ / fkip.unpas.ac.id/.

7 Melly Safitri, Yennita Yennita, and Irdam Idrus, "Upaya Meningkatkan Aktivitas Dan Hasil Belajar Ipa Siswa Melalui Penerapan Model Problem Based Learning (Pbl)," Diklabio: Jurnal Pendidikan Dan Pembelajaran Biologi 2, no. 1 (July 23, 2018): 103-12, https://doi.org/10.33369/diklabio.2.1.103-112. 
atau $67,7 \%$. Pada siklus II keaktifan siswa mengalami peningkatan menjadi 28 siswa dari 30 siswa atau $90 \% 8$.

Berdasarkan uraian di atas, maka perlu diadakan penelitian tindakan kelas untuk membuktikan bahwa penerapan model pembelajaran problem based learning dapat meningkatkan hasil belajar dan aktivitas siswa dalam pembelajaran fisika.

Rumusan masalah dalam penelitian ini adalah apakah penerapan model pembelajaran problem based learning dapat meningkatkan hasil belajar dalam pembelajaran fisika? Hipotesis tindakan pada penelitian ini adalah dengan diterapkan model pembelajaran problem based learning dapat meningkatan hasil belajar dan aktivitas siswa dalam pembelajaran fisika.

Tujuan penelitian adalah untuk mengetahui hasil belajar siswa dalam pembelajaran fisika menggunakan model problem based learning. Manfaat yang diharapkan dari penelitian ini 1) bagi Peneliti dapat memahami pelaksanaan pembelajaran fisika melalui model pembelajaran problem based learning dengan metode praktikum; 2) bagi guru dapat memperbaiki pembelajaran yang dikelolanya; dan 3) bagi sekolah dapat memperbanyak variasi model pembelajaran dan memperbaiki praktik pembelajaran .

Dalam penelitian ini dibangun berdasarkan kajian beberapa teori yakni: pengertian belajar, hasil belajar, dan model pembelajaran problem based learning. Pengertian belajar menurut Kompri adalah serangkaian kegiatan jiwa raga untuk memperoleh suatu perubahan tingkah laku sebagai hasil dari pengalaman individu dalam interaksi dengan lingkungannya yang menyangkut kognitif, afektif, dan psikomotor. 9

Skiner dalam Wahab Jufri menyatakan :"Learning is to observe, to read, to imitate, to try something, themselves, to listen, to follow direction." Dengan kata lain, bahwa belajar adalah mengamati, membaca, meniru, mencoba sesuatu, mendengar dan mengikuti arah tertentu10. Jadi belajar adalah suatu pengalaman hidup seseorang yang didapatkannya dari mulai mengamati sesuatu, membaca yang ada kemudian menirukannya, lalu mencoba sesuatu yang dianggapnya sebagai hal yang baru, dan

\footnotetext{
8 Retno Puji Astuti and Iwan Junaedi, “Peningkatan Aktivitas Dan Hasil Belajar Melalui Pbl Pada Siswa Kelas X Sma," Lembaran Ilmu Kependidikan 42, no. 2 (2013): 93-100, https://journal.unnes.ac.id/nju/index.php/LIK/article/view/2918.

${ }^{9}$ Kompri, Motivasi Pembelajaran, PT Remaja Rosda Karya, Bandung, 2015.

10 Wahab Jufri, Belajar Dan Pembelajaran Sains (Bandung: Pustaka Reka Cipta, 2013), 49.
} 
mendengarkan sesuatu serta mengikuti arah tertentu dalam prosesnya yang menambah wawasannya dari yang belum tahu menjadi tahu

Moh Yamin menyatakan bahwa belajar dapat dimaknai sebagai usaha melakukan perubahan kebiasaan-kebiasaandari tidak baik menjadi baik, dari malas menuju rajin dan begitu seterusnya. Belajar dimaksudkan untuk mampu mencapai perubahan - perubahan pola belajar yang lebih baru, membuka diri, melakukan kebiasaanbelajar yang lebih menarik sekaligus menyenangkan serta tidak membosankan 11

Belajar merupakan pengalaman yang didapatkan seorang individu dalam memodifikasi atau meperteguh kelakuannya, belajar bukan semata-mata hanya tentang mengingat sesuatu yang telah didapatkan lebih dari itu belajar merupakan suatu pengalaman yang harus dialami seseorang

Berdasarkan definisi belajar dari beberapa ahli di atas, dapat disimpulkan bahwa belajar merupakan proses yang dialami seseorang yang dapat merubah pola pikir dan tingkah laku seseorang ke arah yang lebih baik dari sebelumnya.

Sedang menurut Priansa hasil belajar adalah sesuatu hasil yang dicapai atau diperoleh peserta didik berkat adanya usaha atau pikiran yang dinyatakan dalam bentuk penguasaan, pengetahuan, dan kecakapan dasar yang terdapat dalam berbagai aspek kehidupan sehingga tampak perubahan tingkah laku dalam diri individu. ${ }^{12}$

Hasil belajar menurut Bloom dalam Kompri menyatakan bahwa hasil belajar mencakup kemampuan kognitif, afektif dan psikomotorik. Domain kognitif adalah knowledge (pengetahuan, ingatan), comprehension (pemahaman, menjelaskan, meringkas, contoh), application (menerapkan), analysis (menguraikan, menentukan hubungan), sinthesis (mengorganisasikan, merencanakan, membentuk bangunan baru), dan evaluation (menilai). Domain afektif adalah receiving (sikap menerima), responding (memberikan respons), valuing (nilai), organization (organisasi), characterization (karakterisasi). Domain psikomotor meliputi initiatory, pre-routine, dan rountinized ${ }^{13}$. Psikomotor juga mencakup keterampilan produktif, teknik fisik, sosial, manajerial, dan intelektual.

\footnotetext{
11 Moh.Yamin, Teori dan Metode Pembelajaran, Malang: Madani, 2014,hlm. 13

12 Juni Priansa, Donni, Pengembangan Strategi \& Model Pembelajaran, Pustaka Setia, Bandung, 2017.

${ }^{13}$ Kompri, Motivasi Pembelajaran, PT Remaja Rosda Karya, Bandung, 2015
} 
Sedangkan menurut Jenkin dan Uwin dalam Donni Juni Priansa menyatakan bahwa hasil belajar adalah pola-pola perbuatan, nilai-nilai, pengertian-pengertian, sikap-sikap, apresiasi, dan keterampilan. ${ }^{14}$ Dalam penelitian ini yang dimaksud hasil belajar adalah suatu hasil dari proses belajar yang diukur melalui keberhasilan kemampuan kognitif yang diperoleh dari hasil tes belajar setelah mengalami proses satu siklus

Pembelajaran Problem Based learning atau pembelajaran berbasis masalah merupakan sebuah model pembelajran yang memberikan masalah yang kekinian atau kontekstal dalam pembelajaran sehingga dapat merangsang peserta didik untuk belajar. Pembelajaran berbasis masalab atau problem based learning merupakan model pembelajaran yang menantanag peserta didik untu belajar bagaiman belajar. ${ }^{15}$

Menurut Ngalimun pembelajaran berbasis masalah adalah suatu model pembelajaran yang melibatkan siswa untuk memecahkan masalah mealui tahap metode ilmiah sehingga siswa dapat mempelajari pengetahuan yang berhubungan dengan masalah tersebut dan sekaligus memiliki ketrampilan untuk memecahkan masalah ${ }^{16}$.

Tahap-tahap dalam implementasi pembelajaran terbimbing antara lain: mengorientasikan siswa pada masalah, mengorganisasikan siswa untuk belajar, membantu penyelidikan mandiri dan kelompok, mengembangkan dan menyajikan artefak (hasil karya) dan mempamerkannya, analisis dan evaluasi proses pemecahan masalah

\section{METODE PENELITIAN}

Penelitian ini fokus pada penelitian yang dilakukan oleh guru sendiri di kelasnya sendiri melalui refleksi diri dengan tujuan untuk memperbaiki kinerja sehingga hasil siswa meningkat. Jenis penelitian ini adalah penelitian tindakan kelas (PTK). Penelitian ini menggunakan desain penelitian Kemmis Mc Taggart yang dikenal dengan sistem siklus. Artinya dalam satu siklus terdapat suatu putaran kegiatan yang terdiri dari perencanaan, tindakan, pengamatan, dan refleksi. Ketika siklus satu hampir berakhir, namun peneliti masih menemukan kekurangan ketika 2017, hlm. 81

14 Donni Juni Priansa, Pengembangan Strategi \& Model Pembelajaran, Bandung: Pustaka Setia,

15 Suharto,modul guru pembelajar kompetensi D, P4TK, Bandung, 2016, hal. 19

16 Ngalimun, Strategi dan Model Pembelajaran, Aswaja Presindo, Jogyakarta, 2016 
dilakukan refleksi, peneliti bisa melanjutkan pada siklus kedua. Siklus kedua dengan masalah yang sama, namun dengan teknik yang berbeda.

Adapun Desain penelitian tindakan model Kemmis dan Mc Taggart dapat digambarkan sebagai berikut ${ }^{17}$ :

Gambar 1. Desain penelitian tindakan model Kemmis dan Mc Taggart

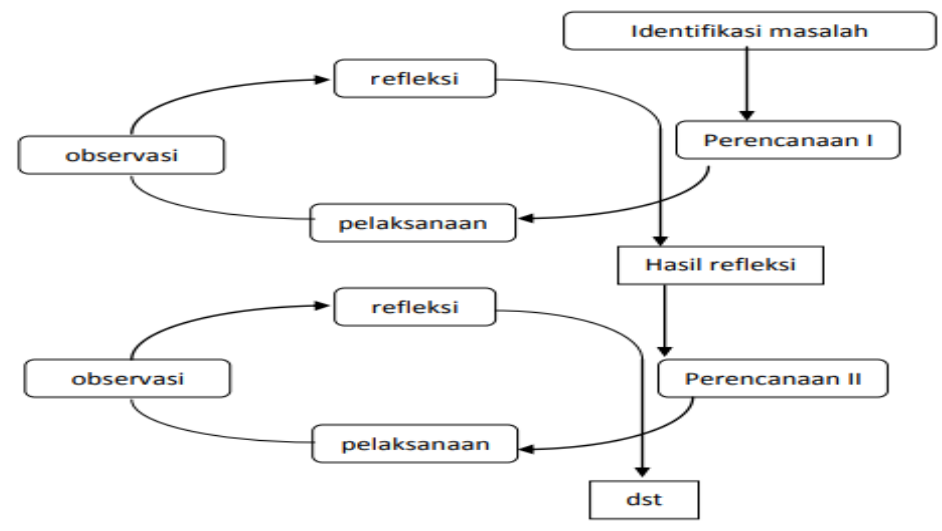

Sumber: Mc Taggart dalam bukunya Zainal Aqib

Penelitian dilaksanakan di kelas XI SMAN 106 Jakarta. Objek penelitian adalah siswa kelas XI - IPA 2 SMAN 106 Jakarta yang berjumlah 36 siswa yang terdiri dari 18 siswa putra dan 18 siswa putri. dan berlangsung dari bulan Februari sampai dengan Mei 2019 tahun pelajaran 2018-2019.

Prosedur yang dilaksanakan dalam penelitian terdiri dari perencanaan, pelaksanaan, pengamatan dan refleksi. 1). Tahap perencanaan meliputi: (a). mengidentifikasi masalah yang dialami peserta didik, (b) merumuskan pilihan tindakan yang dilakukan, menyusun RPP, (c) menentukan metode pengumpulan data dan (d) analisis data. 2). Tahap pelaksanaan meliputi: a). Pendahuluan yang meliputi : (1) Berdo'a, (2) menginformasikan KD dan indikator pencapaian kompetensi, (3) pengetahuan prasarat. b). Kegiatan Inti yang terdiri dari : (1). Fase 1 yaitu Orientasi siswa terhadap masalah yang meliputi: menjelaskan tujuan pembelajaran, menjelaskan logistic yang dibutuhkan dan memotivasi iswa untuk terlihat aktif dalam pemecahan masalah yang dipilih. (2). Fase 2 yaitu mengorganisasikan siswa yang meliputi : membantu siswa mendefinisikan masalah, membentuk kelompok, mengorganisasikan tugas belajar yang berhubungan dengan masalah. (3). Fase 3 yaitu embimbing

17 Zainal Aqib, Siti Jaiyaroh,Eko Diniati dan Khusnul Khotimah, Penelitian Tindakan Kelas,Bandung, Yrama Widya,cetakan ke 3, 2011 
penyelidikan individu dan kelompok yang meliputi : mengarahkan peserta didik untuk bekerja secara kelompok, peserta didik melakukan percobaan atau kegiatan sesuai LKS, setiap kelompok menjawab berbagai masalah yang diajukan dalam LKSg, uru membimbing siswa dalam memacahkan masalah. (4). Fase 4 yaitu mengembangkan dan menyajikan hasil karya yang meliputi : diskusi konsep untuk memecahkan masalah, mempresentasikan hasil diskusi, mempresentasikan hasil diskusi. (5). Fase 5 yaitu menganalisis dan mengevaluasi proses pemecahan masalah yang meliputi : diskusi kelas untuk menganalisis hasil pemecahan masalah dan menyamakan persepsi tentang pemecahan masalah pada LKS diman peserta didik diharapkan menggunakan buku sumber untuk mengetahui bantuan mengevaluasi hasil diskusi. c). Penutup yang meliputi : peserta didik diminta menyimpulkan tentang hasil pembelajaran, memberi tugas PR dan mengakhiri dengan berdo'a . 3). Pengamatan yang dilakukan selama proses pembelajaran berlangsung. Dalam pengamatan ini akan diungkap segala peristiwa yang berhubungan dengan pembelajaran, baik aktivitas peserta didik melakukan kegiatan pembelajaran, maupun respon peserta didik terhadap teknik pembelajaran. 4). Tahap refleksi meliputi: (a). evaluasi mutu, jumlah dan waktu dari setiap tindakan yang dilakukan dalam proses pembelajaran; (b). pertemuan untuk membahas hasil evaluasi tentang RPP dan lembar kerja siswa, dengan melihat hasil observasi guru dan siswa; (c). Perbaikan pelaksanaan tindakan sesuai hasil evaluasi untuk digunakan pada siklus berikutnya

Data yang dikumpulkan meliputi data hasil tes. Adapun sumber data terdiri dari siswa, guru dan teman sejawat serta kolaborator. Jenis data adalah hasil tes dan sumber lain seperti buku, online, dokumen, dll

Waktu pelaksanaan penelitian tindakan kelas (PTK) dilakukan sesuai jadwal mengajar sebanyak 6 pertemuan. Materi PTK untuk siklus I ialah kompetensi dasar menerapkan hukum-hukum fluida statik dalam kehidupan sehari-hari, yang dilaksanakan sebanyak 3 pertemuan. Siklus I dilaksanakan pada bulan September 2020. Materi siklus II adalah kompetensi dasar menerapkan prinsip fluida dinamik dalam teknologi yang dilaksanakan sebanyak 3 pertemuan. Siklus II dilaksanakan pada bulan oktober 2020. Sedang penyusunan laporan hasil penelitian dilakukan pada bulan Oktober 2020. 
Analisis data menggunakan teknik analisis kualitatif dan kuantitatif deskriptif. Data yang sudah terkumpul dideskripsikan untuk kemudian dihitung secara statistik untuk mengetahui statistik deskrtiptifnya.

Indikator keberhasilan dalam penelitian ini dikatakan berhasil ialah jika hasil belajar siswa secara klasikal memperoleh rata-rata $\geq 75$ dan ketuntasan belajar siswa $\geq$ $75 \%$.

\section{HASIL DAN PEMBAHASAN}

Siklus 1

Pelaksanaan siklus I dengan materi gelombang bunyi. Siklus I dilaksanakan selama dua pertemuan (8 jam tatap muka). Setelah selesai pelaksanaan proses pembelajaran siklus I, dilaksanakan tes tertulis untuk mendapatkan data hasil belajar, kemudian data tersebut dianalisis untuk mendapatkan informasi tentang peningkatan hasil belajar. Adapun data hasil belajar pada siklus I disajikan pada tabel berikut:

Tabel 1. Data hasil belajar siklus I .

\begin{tabular}{ll}
\hline Rentang & Frekuensi Siklus I \\
\hline $95-100$ & 0 \\
\hline $85-94$ & 14 \\
\hline $75-84$ & 17 \\
\hline$<75$ & 5 \\
\hline Rata-rata & 80 \\
\hline NR & 50 \\
\hline NT & 90 \\
\hline Siswa Tuntas & 31 \\
\hline Ketuntasan & $86.1 \%$ \\
\hline Siswa Tidak Tuntas & 5 \\
\hline
\end{tabular}

Dari analisis hasil ulangan pada tabel diatas diperoleh nilai rata-rata kelas 80,00 dan tingkat ketuntasan $86.1 \%$. Sedang siswa yang sudah tuntas sebanyak 31 siswa dan yang tidak tuntas sebanyak 5 siswa. Dari analisis hasil tersebut maka pembelajaran secara klasikal dapat dinyatakan tuntas karena siswa yang sudah tuntas lebih dari $75 \%$. Sedang siswa yang belum tuntas akan diberi pembelajaran remidial secara individual. Hasil ini meningkat dibanding dari hasil yang diperoleh sebelum menggunakan pembelajaran dengan model problem based learning pada pertemuan sebelum (pra-siklus).

Setelah dilakukan observasi dalam proses pembelajaran siklus I terhadap 
aktifitas belajar siswa, observasi guru dalam proses pembelajaran dan hasil belajar siswa, maka dilakukan refleksi. Refleksi bertujuan untuk mengidentifikasi hal-hal positif dan masalah-masalah yang muncul pada siklus I dan akan diperbaiki pada siklus II dengan memberikan perlakuan-perlakuan (treatment) tertentu.

Adapun masalah yang teridentifikasi dalam pelaksanaan pembelajaran siklus I adalah sebagai berikut : (1). Hasil evaluasi pembelajaran pada siklus I memperoleh nilai rata-rata kelas 80,00 dan tingkat ketuntasan mencapai $86.1 \%$. Sedang siswa yang sudah tuntas sebanyak 31 siswa dan yang tidak tuntas sebanyak 5 siswa. Dari analisis hasil tersebut maka pembelajaran secara klasikal dinyatakan telah tuntas, karena siswa yang telah tuntas sudah lebih dari $75 \%$. Maka model problem based learning pada tahap ini sudah dinyatakan berhasil meningkatkan hasil belajar siswa. (2). Masih ditemukan ada kelemahan pada diri siswa dalam menyampaikan atau mempresentasikan hasil penelitian/pengamatan. Untuk memperbaiki kelemahan dan mempertahankan keberhasilan yang telah dicapai pada siklus [, maka pelaksanaan pada siklus II dapat dibuat perencanaan sebagai berikut : (1). Memberikan materi atau informasi pada saat akan diadakan kegiatan praktikum untuk memecahkan masalah, yaitu siswa diminta membaca petunjuk secara seksama sebelum kegiatan dimulai. (2). Menjaga agar kelompok terus memusatkan perhatian pada pencapaian tujuan tidak ada siswa dalam kelompok yang mengerjakan tugas laian atau aktivitas lain kecuali bekerja sesuai tuntutan LKS. (3). Memonitor jalannya diskusi (berkeliling tiap kelompok) dan membuat catatan tentang berbagai masalah yang muncul dalam proses belajar mengajar agar proses belajar terus berlangsung, agar tidak ada tahapan dalam proses belajar yang dilewati atau diabaikan dan agar tiap tahapan dilakukan dalam urutan yang tepat.(4) Menjaga motivasi siswa dengan mendorong siswa keluar dari kesulitannya dengan cara mencari sumber informasi melalui browsing dan literatur yang dibawa. (5). Membimbing proses belajar dengan mengajukan pertanyaan yang tepat pada saat yang tepat, yang lebih mendalam tentang berbagai konsep,ide, penjelasan, sudut pandang dan lain- lain yaitu pada saat pengambiln keputusan atau diskusi. (6). Memberikan kesempatan kepada masing-masing kelompok untuk maju di depan kelas dan mengungkapkan hasil diskusi kelompoknya dengan gaya dan bahasa sendiri

\section{Siklus II}


Pada pelaksanaan siklus II diadakan perbaikan guna memperbaiki kekurangan pada siklus I. Adapun perbaikan tersebut yakni: 1). Memberikan materi atau informasi pada saat akan diadakan kegiatan praktikum untuk memecahkan masalah,yaitu siswa diminta membaca petunjuk secara seksama sebelum kegiatan dimulai. 2). Menjaga agar kelompok terus memusatkan perhatian pada pencapaian tujuan tidak ada siswa dalam kelompok yang mengerjakan tugas laian atau aktivitas lain kecuali bekerja sesuai tuntutan LKS. 3). Memonitor jalannya diskusi (berkeliling tiap kelompok) dan membuat catatan tentang berbagai masalah yang muncul dalam proses belajar mengajar agar proses belajar terus berlangsung, agar tidak ada tahapan dalam proses belajar yang dilewati atau diabaikan dan agar tiap tahapan dilakukan dalam urutan yang tepat. 4). Menjaga motivasi siswa dengan mendorong siswa keluar dari kesulitannya dengan cara mencari sumber informasi melalui browsing dan literatur yang dibawa. 5). Membimbing proses belajar dengan mengajukan pertanyaan yang tepat pada saat yang tepat, yang lebih mendalam tentang berbagai konsep,ide, penjelasan, sudut pandang dan lain- lain yaitu pada saat pengambiln keputusan atau diskusi. 6). Memberikan kesempatan kepada masing-masing kelompok untuk maju di depan kelas dan mengungkapkan hasil diskusi kelompoknya dengan gaya dan bahasa sendiri untuk menyimpulkan hasil pembelajaran sesuai materi yang dipelajari

Setelah pelaksanaan pembelajaran siklus II selesai, maka diadakan tes untuk dianalisis. Tes siklus II dilaksanakan dengan tes tertulis dengan bentuk pilihan ganda ( PG ). Adapun hasil belajar pada siklus II dapat disajikan pada tabel berikut :

Tabel 2. Ketercapaian hasil belajar pada siklus II

\begin{tabular}{ll}
\hline Rentang & Frekuensi Siklus II \\
\hline $\mathbf{9 5}$ - $\mathbf{1 0 0}$ & 21 \\
$\mathbf{8 5 - \mathbf { 9 4 }}$ & 9 \\
$\mathbf{7 5}-\mathbf{8 4}$ & 5 \\
$\mathbf{2} \mathbf{7 5}$ & 1 \\
Rata-rata & 92 \\
NR & 53 \\
NT & 100 \\
Siswa Tuntas & 35 \\
Ketuntasan(\%) & 97.20 \\
Siswa Tidak Tuntas & 1 \\
\hline
\end{tabular}


Dari analisi ulangan pada siklus II seperti table di atas tinggal satu siswa yang belum tuntas. Nilai rata-rata hasil belajar pada siklus II mencapai 92. Dan tingkat ketuntasan mencapai 97,20 \% hal ini menunjukan bahwa secara klasikal pembelajaran sudah tuntas, karena sudah mencapai diatas $75 \%$. Siswa yang remedial tinggal satu siswa, sehingga cukup diberikan kegiatan remidial perorangan.

Berdasarkan hasil analisis dan evaluasi data pada siklus II diperoleh gambaran bahwa menggunakan model problem based learning ( PBL ) telah efektif digunakan dalam proses pembelajaran. Perhatian guru terhadap siswa sudah meningkat dan tidak hanya pada sebagian siswa melainkan seluruh siswa. Motivasi siswa untuk terlibat didalam kegiatan belajar cukup tinggi. Siswa lebih percaya diri dan lebih berani mengungkapkan pendapat dan lebih aktif dalam proses belajar mengajar. Kegiatan siswa dalam melakukan langkah-langkah problem based learning seperti melakukan pemecahan masalah, interaksi antara siswa dengan siswa, merumuskan prinsip dan generalisasi penemuan, serta melakukan penyelidikan terhadap permasalahan yang diajukan guru telah mengalami peningkatan dibandingkan siklus pertama dan memenuhi indikator pencapaian keberhasilan dengan kategori baik. Hasil belajar yang diperoleh siswa telah mencapai indikator pencapaian keberhasilan.

\section{Pembahasan}

Hasil belajar adalah sesuatu yang dicapai atau diperoleh peserta didik berkat adanya usaha atau pikiran yang dinyatakan dalam penguasaan pengetahuan, dan kecakapan dasar yang tedapat dalam berbagai aspek kehidupan sehingga tampak perubahan tingkah laku ${ }^{18}$ onni Juni Priansa, Pengembangan Strategi Dan Model Pembelajaran, 1st ed. (Bandung: CV.Pustaka Setia, 2017).

Adapun factor-faktor yang mempengaruhi bahwa hasil belajar menurut Syah dalam Priansa antara lain ${ }^{19}: 1$ ). Faktor internal (factor dari dalam peserta didik). 2). Faktor internal meliputi aspek fisiologis dan psikologis. Aspek fisiologis berkaitan dengan jasmani peserta didik, sedang aspek psikologis berkaitan dengan rohaniah peserta didik yang meliputi intelegensia peserta didik, sikap peserta didik, bakat peserta didik, minat peserta didik dan motivasi peserta didik. 3). Faktor eksternal ( faktor dari luar peserta didik), yaitu kondisi lingkungan di sekitar peserta didik. Faktor

18 Juni Priansa, Donni, Pengembangan Strategi \& Model Pembelajaran, Pustaka Setia, Bandung,

19 Juni Priansa, Donni, Pengembangan Strategi \& Model Pembelajaran, Pustaka Setia, Bandung, 2017 
eksternal terdiri dari lingkungan social dan linkgungan non sosial. 4). Faktor pendekatan belajar atau approach to learning menyangkut strategi dan metode yang digunakan dalam pembelajaran.

Maka jelaslah bahwa srategi, metode maupun pendekatan guru dalam proses pembelajaran akan mempengaruhi hasil belajar peserta didik. Maka guru harus bisa memilih srategi, pendekatan atau metode pembelajaran, agar proses pembelajaran berjalan efektif. Jika proses pembelajaran efektif diharapkan tujuan pembelajaran tercapai, sehingga dapat meningkatkan hasil belajar peserta didik.

Peneliti menerapkan model problem based learning dalam proses pembelajaran, dimana peserta didik dibagi menjadi kelompok yang masingmasing terdiri 6 orang. Langkah-langkah pembelajaran model problem based learning yaitu orientasi siswa terhadap masalah, mengorganisasi siswa, membibimbing penyelidikan individu dan kelompok, mengembangkan dan menyajikan hasil karya, menganalisis dan mengevaluasi terhadap proses pemecahan masalah, serta evaluasi.

Berdasarkan hasil pengamatan terhadap proses dan hasil belajar peserta didik pada pelaksanaan siklus I , untuk proses pembelajaran perlu perbaikan, karena masih ada beberapa siswa yang belum terlibat aktif dalam kegiatan pembelajaran. Kelemahan utama pada pelaksanaan siklus I yaitu proses dalam menyampaikan mempresentasikan hasil penelitian/pengamatan.

Sedang hasil analisis hasil tes yang dilakukan pada siklus I, terdapat 31 peserta didik $(86,1 \%)$ yang tuntas dan 5 peserta didik (13,8\%) yang belum tuntas. Nilai rata-rata yang dicapai peserta didik adalah 80,00. Dari analisis hasil ulangan pada siklus I memberi gambaran bahwa ketuntasan belajar telah mengalami peningkatan sebesar $20 \%$, dari proses pembelajaran sebelum diterapkan model pembelajaran problem based learning (pra siklus) yang memiliki ketuntasan 66,6\%. Sedang nilai rata-rata juga mengalami peningkata sebesar 20 poin dari 72,00 pada pra siklus menjadi 80,00 pada siklus I.

Setelah mengalami perbaikan dalam proses pembelajaran pada pelaksanaan siklus II, dan diadakan evaluasi, diperoleh rata-rata hasil belajar peserta didik sebesar 92,00. Peserta didik yang tuntas sebanyak 35 peserta didik (97,2\%). Angka tersebut menunjukkan terjadi peningkatan hasil belajar fisika sebesar $11,1 \%$ 
sehingga pelaksanaan penelitian dihentikan karena sudah menunjukan peningkatan secara kontinyu. .

Berdasarkan hasil yang dicapai peserta didik, disimpulkan bahwa hasil belajar fisika peserta didik dapatitingkatkan melalui pembelajaran dengan penerapan model pembelajaran problem based learnng. Penerapan model pembelajaran problem based learnng yang dapat meningkatkan hasil belajar fisika, sesuai hasil penelitian ini adalah sebagai berikut, pembelajaran dimulai dengan 1). Pendahuluan ( mendata peserta didik yang tidak hadir, berdo'a, menginformasikan KD dan indikator pencapaian kompetensi,menyampaikan pengetahuan prasarat), 2). Kegiatan inti, yang meliputi: a). Orientasi siswa terhadap masalah (peserta didik dihadapkan pada masalah dengan menpilkan video atau emontrasi, atau berupa pertanyaan). b). Mengorganisasikan siswa (embantu siswa mendefinisikan masalah , membentuk kelompok secara heterogeny, membagi LKS). c). Membimbing penyelidikan individu dan kelompok (mengarahkan peserta didik untuk bekerja secara kelompok, peserta didik melakukan percobaan atau kegiatan sesuai LKS, setiap kelompok menjawab berbagai masalah yang diajukan dalam LKS). d). Mengembangkan dan menyajikan hasil karya (diskusi konsep untuk memecahkan masalah, Mempresentasikan hasil diskusi). e). Menganalisis dan mengevaluasi proses pemecahan masalah (diskusi kelas untuk menganalisis hasil pemecahan masalah dan menyamakan persepsi tentang pemecahan masalah pada LKS. Peserta didik diharapkan menggunakan buku sumber untuk mengetahui bantuan mengevaluasi hasil diskusi). 3). Kegiatan penutup (peserta didik diminta membuat kesimpulan, memberi tugas, berdo'a)

\section{KESIMPULAN}

Berdasarkan analisis data dan pembahasan yang telah diuraikan sebelumnya, maka dapat disimpulkan bahwa pembelajaran fisika dengan menggunakan model problem based learning dapat meningkatkan hasil belajar siswa. Selain itu, berdasarkan data observasi, dapat terlihat bahwa pembelajaran fisika dengan menggunakan model problem based learning pada siklus II lebih baik dibandingkan dengan siklus I. Hal ini terjadi karena pada siklus II terdapat perbaikan tindakan yang dilakukan oleh peneliti, seperti pengaturan waktu yang lebih proporsional, peningkatan pengawasan guru terhadap seluruh siswa dan memeriksa bahwa semua siswa memahami tujuan dan 
prosedur kegiatan yang harus dilakukan, memberikan motivasi kepada siswa serta adanya pembagian tugas yang merata kepada anggota kelompok masing-masing sehingga semua siswa terlibat dalam memecahkan masalah dan memperhatikan proses penemuan yang dilakukan.

Dari analisis hasil tes yang dilakukan pada siklus I, terdapat 31 peserta didik $(86,1 \%)$ yang tuntas dan 5 peserta didik $(13,8 \%)$ yang belum tuntas. Nilai ratarata yang dicapai peserta didik adalah 80,00. Dan pada siklus II rata-rata hasil belajar peserta didik sebesar 92,00. Peserta didik yang tuntas sebanyak 35 peserta didik (97,2\%). Dari analisis hasil ulangan pada siklus I memberi gambaran bahwa ketuntasan belajar telah mengalami peningkatan sebesar $20 \%$ pada siklus I dan 11,1 pda siklus II 30,6 \%, dari proses pembelajaran sebelum diterapkan model pembelajaran problem based learning (pra siklus) yang memiliki ketuntasan 66,6\%.

Dari analisis hasil tes juga diperoleh bahwa nilai rata-rata juga mengalami peningkata sebesar 8 poin dari 72,00 pada pra-siklus menjadi 80,00 pada siklus I dan pada siklus naik 20 poin dari 72,00 menjadi 92,00. Hal ini menunjukkan bahwa dengan diterpkannya model pembelajaran berbasis problem based learning telah terjadi peningkatan hasil belajar fisika sebesar 11,1\%, dan secara konsisten sudah menunjukan peningkatan secara kontnyu. .

Dengan demikian, maka berdasarkan data-data di atas dapat disimpulkan bahwa aktivitas belajar siswa dan hasil belajar siswa mengalami peningkatan dengan menggunakan problem based learning karena telah mencapai kriteria indikator keberhasilan yang telah ditetapkan.

\section{REFERENSI}

A. Rusdiana. Konsep Inovasi Pembelajaran. Bandung: Pustaka Setia, 2014.

Alda, Rivika, Helen Boholano, and Filomena Dayagbil. “Teacher Education Institutions in the Philippines towards Education 4.0." International Journal of Learning, Teaching and Educational Research 19, no. 8 (September 26, 2020). http://www.ijlter.org/index.php/ijlter/article/view/2449.

Ardianti, Sekar Dwi, Savitri Wanabuliandari, Sigit Saptono, and Siti Alimah. "Respon Siswa Dan Guru Terhadap Modul Ethno-Edutainment Di Sekolah Islam Terpadu." Edukasia : Jurnal Penelitian Pendidikan Islam 14, no. 1 (June 24, 2019): 1-24. https:/ / doi.org/10.21043/edukasia.v13i2.3693. 
Arifin, Zainal. "Lingkungan Pendidikan Berperan Aktif Menumbuhkan Motivasi Belajar Siswa Menurut Syaikh Al-Zarnuji, Dalam Kitab Ta'limul Muta'allim." Al Qodiri: Jurnal Pendidikan, Sosial Dan Keagamaan 7, no. 2 (2014): 32-40.

ASRI FITRIANI ALIFAH. “Upaya Peningkatan Hasil Belajar Siswa Dengan Model Problem Based Learning (Pbl) Pada Subtema Hidup Rukun Dirumah (Penelitian Tindakan Kelas Di Kelas Ii Sdn 025 Cikutra Kota Bandung)." Other, FKIP UNPAS, 2018. http:/ / fkip.unpas.ac.id/.

Astuti, Retno Puji, and Iwan Junaedi. "Peningkatan Aktivitas Dan Hasil Belajar Melalui Pbl Pada Siswa Kelas X Sma." Lembaran Ilmu Kependidikan 42, no. 2 (2013): 93100. https://journal.unnes.ac.id/nju/index.php/LIK/article/view/2918.

Darmadi, Hamid. “Tugas, Peran, Kompetensi, Dan Tanggung Jawab Menjadi Guru Profesional." Edukasi: Jurnal Pendidikan 13, no. 2 (April 23, 2016): 161-74. https://doi.org/10.31571/edukasi.v13i2.113.

Darmawan, Deni. Inovasi Pendidikan, Pendekatan Praktik Teknologi Multimedia Dan Pembelajaran Online. Ketiga. 3. Bandung: PT Remaja Rosdakarya, 2014.

Jufri, Wahab. Belajar Dan Pembelajaran Sains. Bandung: Pustaka Reka Cipta, 2013.

Juni Priansa, Donni. Pengembangan Strategi Dan Model Pembelajaran. 1st ed. Bandung: CV.Pustaka Setia, 2017.

Ngalimun, S. Pd, and M. Pd. "Strategi Dan Model Pembelajaran." Yogyakarta: Aswaja Pessindo, 2014.

Safitri, Melly, Yennita Yennita, and Irdam Idrus. “Upaya Meningkatkan Aktivitas Dan Hasil Belajar Ipa Siswa Melalui Penerapan Model Problem Based Learning (Pbl)." Diklabio: Jurnal Pendidikan Dan Pembelajaran Biologi 2, no. 1 (July 23, 2018): 103-12. https://doi.org/10.33369/diklabio.2.1.103-112.

Saleh, Marhamah. "Strategi Pembelajaran Fiqh Dengan Problem-Based Learning." Jurnal Ilmiah Didaktika: Media Ilmiah Pendidikan Dan Pengajaran 14, no. 1 (August 1, 2013). https:/ / doi.org/10.22373/jid.v14i1.497.

Satriawan, Muhammad, and Rosmiati Rosmiati. "Pengembangan Bahan Ajar Fisika Berbasis Kontekstual Dengan Mengintegrasikan Kearifan Lokal Untuk Meningkatkan Pemahaman Konsep Fisika Pada Mahasiswa." JPPS (Jurnal Penelitian Pendidikan Sains) 6, no. 1 (2017): 1212-17.

Suharto, modul guru pembelajar kompetensi D, P4TK, Bandung, 2016. 
Yamin, Moh, Teori dan Metode Pembelajaran, Malang: Madani, 2014.

Zainal, Aqib, Siti Jaiyaroh,Eko Diniati dan Khusnul Khotimah, Penelitian Tindakan Kelas,Bandung, Yrama Widya,cetakan ke 3, 2011 